UDK 528.44

\title{
THE SUBSTANTIATION OF URBAN HABITATS PEER LAND EXCHANGE IN UKRAINE
}

\author{
Mykola MALASHEVSKYI ${ }^{1}$, Olena BUGAIENKO ${ }^{2}$ \\ Land Management, Cadastre and Geoinformatics Department, Institute of Advanced Education of Kyiv \\ National University of Construction and Architecture, 4, Osvity Street, Kyiv, 03680, Ukraine \\ E-mails: ${ }^{1}$ mykola.malashevskyi@gmail.com; ${ }^{2}$ lena_bugaenko@mail.ua (corresponding author)
}

Received 15 March 2016; accepted 03 June 2016

\begin{abstract}
Land exchanges have been used around the world and are recognized as one of the principal ways of land reallocation. At the moment, placement of facilities and socially and environmentally important objects in the existing housing is of special importance in Ukraine. There is a need for finding ways of increasing the effectiveness of such projects with the help of peer exchange. With this aim, engineering solutions for the built-up land exchange should be found.

Research, provided in this paper, aims at substantiating peer land plot exchange calculation at the inhabited locality improvement. Key factors defining value of the built-up land (or the land to be built-up) have been defined. Placement and physical characteristics, which should be taken into consideration to achieve the land exchange equality, have been singled out.

Based on the existing calculation of peer agricultural land exchange in Ukraine a methodology for built-up (or to be built-up) land, which considers the peculiarities of the land usage, has been proposed.

Calculation of peer built-up (or that to be built-up) urban land exchange has been presented. Technical data characterizing the main influence factors in the discourse of the provided land exchange approach have been offered. The calculation algorithm on the example of peer residential housing land plot exchange in Kyiv has been provided.
\end{abstract}

Keywords: land survey, land exchange, peer land plots, urban territory development, land reallotment, large-scale infrastructure projects.

\section{Introduction}

In Ukraine, like in most countries, urban land usage improvement is an important issue. At the moment, a variety of public purposes is restrained due to the need for adjusting the interests of private owners or territorial communities. The gist of the problem is the need for allocating the land for the transport infrastructure objects, formation of safety zones, industrial objects land plots area optimization, at adjustment and shifting the limits of inhabited localities. The effectiveness of these projects in the first place depends on the degree to which the land owners' losses are avoided.

In Ukraine, the process of land withdrawal in terms of compensation and recovery for losses as a rule causes a long-term agreement process, which often can't reach the ultimate purpose. In these conditions, one of the primary ways of the existing land tenure reallotment is the peer exchange. Land exchange procedure is predefined by the legislation of Ukraine, there are examples of land exchange. However, the appropriate measures are of local character, the exhaustive technical substantiation is necessary for the peer exchange at implementing large-scale projects.

\section{Peer exchange at land reallotment}

Land rearrangement can be an effective mechanism of urban territory development (De Moor 2015). Possibilities for placing the public facilities for large-scale infrastructure projects, environmentally and socially important objects as the result of land rearrangement is carefully considered in the complex land consolidation projects (FAO 2003, 2004; Attenberger 2002). There is a set of researches envisaging the analysis of 
such projects practical realization and the possibility for application of land exchange to the projects is determined. For example, there are cases of the ownership problem effective solution at the placement of industrial facilities in the existing housing, land allocation for the protection of the stretch of water (Drees 2002), road construction (Drees 2002; Attenberger 2002; Hendricks, Lisec 2013; Thomas 2012), the issue of squatting possible solutions have been defined (Giovarelli, Bledsoe 2001).

Land exchange in the above-mentioned cases is generally based on the relevant country's legislation. The larger the experience of the legislative regulation of the relevant measures and adaptation to the peculiarities of the state and clearer the optimization criteria, the more effective and fast is resolving the problem. International organizations have provided recommendations on the existing land tenure improvement measures implementation in Eastern Europe states (FAO 2003, 2004; Hartvigsen 2014, 2015; Giovarelli, Bledsoe 2001; Thomas 2006). However, the technical input of land exchange has not been addressed in the above-mentioned researches. Adapting the international experience of large-scale urban land tenure improvement measures using peer exchange to Ukraine environment demands determination of clear optimization criteria. Thus, minimization of impact of a set of administration and political factors on the peer land exchange measures realization is possible.

Technical substantiation of peer exchange in Ukraine exists for agricultural land. According to the existing methodology, peer land plots are calculated at dimensions defect correction, area composition, limits and spatial arrangement of agricultural land plots (Malashevskyi et al. 2014). General principle of avoiding the land owners' losses is the basis of peer land plots determination. At the moment, a formula considering the area of peer land plots and quality of soil as the core indicators is used for peer agricultural land plots exchange computation:

$$
S_{i} B_{i}=S_{k} B_{k},
$$

where $S$ is the area of land plots $i$ and $k ; B$ is the ballbonitet of the corresponding land plot soil (specifies the soil quality by the core natural and acquired properties from the point of view of growing basic crops by 100-point scale).

Normally, exchange of any purpose land is considered peer in case the land plots to be exchanged by the cumulative of their core natural and acquired properties are of the same value from the point of view of their general functional role (Bugaienko 2015). This formula can be the basis for peer urban land plots calculation provided the core factors influencing the value of the corresponding land are considered.

\section{The core factors influencing the peer exchange}

The inhabited locality land plays the role of the spatial basis, therefore placement and existing facilities must be primarily taken into consideration at peer land exchange. For the built-up inhabited area land plots (or the ones to be built-up) of the equal functional usage at the peer exchange should be taken into consideration:

- placement in a certain category inhabited locality, a certain economic planning zone in the inhabited locality and characteristics of the surrounding area usage. Inhabited localities are differentiated according to their administrative status, economic functions and population, geographic position, placement in the suburban zone of big cities, in the zone of technogenic pollution. Economic planning zones are set based on the economic valuation of the inhabited locality considering inhomogeneity of the territory functional planning qualities, accessibility of work places, public services, recreation zones, city centre, engineer assistance, land improvements, public infrastructure development, territory environment quality, work place placement diversity, historical, cultural and natural places of interest, housing architectural aesthetics, etc. (Derzhavnyi komitet Ukrainy... 2006). The neighbor territory is characterized from the point of view of the peculiarities of placement in a certain economic planning zone. Pedestrian connectivity to the objects of transport facilities, public centres and recreation, placement in nature conservation, recreational territories, historical and cultural places of interest, etc.;

- land plot physical characteristics: area, configuration, surface slope, soil conditions, groundwater conditions and flood pattern, placement in the dangerous geological processes zone, availability of major water-, gas-, heat supply networks, waste-water disposal systems, adjoining street surface, real estate units structure and status;

- mortgages and easements or servitudes. 


\section{Peer land plots calculation}

The gist of peer exchange is land plots comparison. As the calculation result, the determination of the land plot area, peer to the given one, taking into consideration the initial area of the land plot to be exchanged and major characteristics of both land plots, is considered. Peer exchange of the built-up (or to be built-up) inhabited locality land plots of the same functional usage can be described by the following equation:

$$
S_{i} \times K_{p l i} \times K_{p h i} \times K_{e i}=S_{k} \times K_{p l k} \times K_{p h k} \times K_{e k},
$$

where $S$ - land plot area; $K_{p l}$ - correction factor for land plot placement; $K_{p h}$ - correction factor for land plot physical characteristics; $K_{e}$ - factor characterizing the existence of easements or servitudes.

$K_{p l}$ value is calculated as the product of separate factors depending on the presence of certain characteristics defining them, by the formula which includes the factor of placement in a certain category inhabited locality, in a certain economic planning zone in the inhabited locality and the neighbour territory usage characteristics. Relevant factors $\left(K_{\mathrm{p} l}, K_{\mathrm{p} 2}\right)$, defined at the monetary valuation of the inhabited localities lands of Ukraine (Derzhavnyi komitet Ukrainy... 2006), can be used as the relevant correction factors. Corrections for the neighbour territory usage can be executed resulting from local factors $\left(K_{p 3}\right)$ according to the monetary valuation of the inhabited localities land of Ukraine (Derzhavnyi komitet Ukrainy... 2006).

$K_{p h}$ factor characterizes the joint impact of configuration, surface slope, soil conditions, ground-water conditions and flood pattern, placement in the dangerous geological processes zone, availability of major water-, gas-, heat supply networks, waste-water disposal systems, adjoining street surface, real estate units structure and status factors. Joint factor is the product of relevant factors.

For valuation of the land plot configuration the alignment index which can be found by the equation (Chibiriakov et al. 2015) is suggested:

$$
K_{f}=\sqrt{2} \frac{\sum_{i=1}^{n} \frac{r_{\min }^{i}}{r_{\max }^{i}}}{n},
$$

where $r^{i}$ - maximum and minimum distance from the centre of the land plot to side $i$; $n$ - quantity of sides.

To reflect other criteria, engineering-geological and engineering-infrastructural local factors $\left(K_{p 3}\right)$ defined by the inhabited localities land of Ukraine monetary value (Derzhavnyi komitet Ukrainy... 2006), can be used. If the defined factors are not present for the land plot to be researched, the relevant factor is taken to be equal to 1 .

\section{The example of peer residential housing land exchange calculation}

It is assumed, that with the aim of land tenure improvement a land plot with the area of $S_{i}=1200$ sq. m. in Obolon district of Kyiv is to be exchanged. According to technical documentation on the monetary valuation the factor characterizing the land plot placement for the capital of Ukraine equals to $K_{p 1}=3.00$ (Kyivska miska administratsiia 2007). According to zoning the land plot is situated in the economic planning zone No. 433 . Factor characterizing the land plot placement in the economic planning zone equals to $K_{p 2}=0.62$ (Kyivska miska administratsiia 2007). The land plot is situated in the advanced city-forming importance major highway zone $\left(K_{p 3}=1.20\right)$ and recreational purpose zone $\left(K_{p 3}=\right.$ 1.09) (Kyivska miska administratsiia 2007). Functional usage of the land plot is the land of residential housing. The land plot (Fig. 1) has a rectangular form (according to formula (3) $K_{f}=0.99$ ), in the ground-water occurrence zone less than $3 \mathrm{~m}\left(K_{p 3}=0.95\right)$, underflooding of more than $4 \%$ probability (submerge level more than 2 m) $\left(K_{p 3}=0.95\right)$, no central water supply $\left(K_{p 3}=0.95\right)$, no gas supply $\left(K_{p 3}=0.95\right)$, no sewage $\left(K_{p 3}=0.95\right)$, and no heat supply $\left(K_{p 3}=0.95\right)$ (Kyivska miska administratsiia 2007). Real estate units are not situated on the land plot, no easements or servitudes $\left(K_{e}=1.00\right)$.

For calculation by the Equation (2) its principal constituents are specified:

$$
K_{p l 1}=3.00 \times 0.62 \times 1.20 \times 1.09=2.43 ;
$$

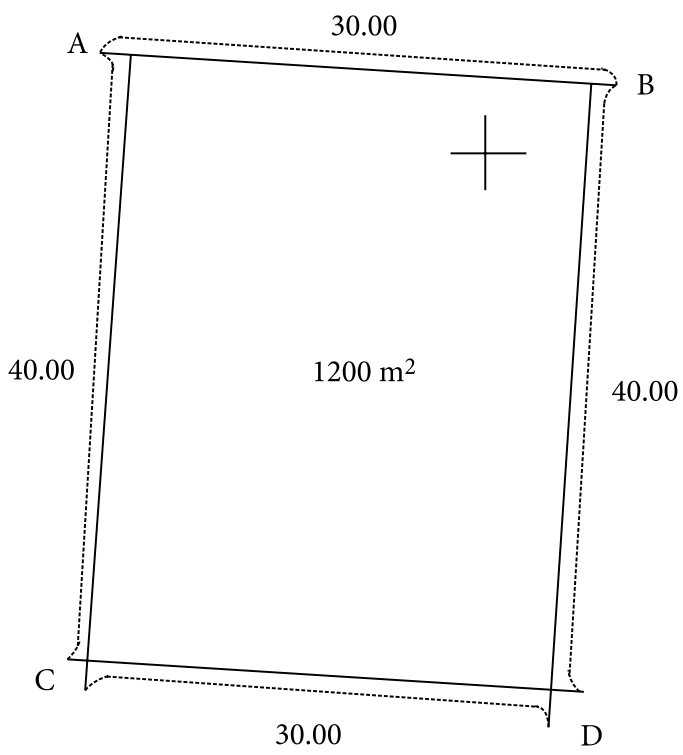

Fig. 1. The land plot to be exchanged 
$K_{p h 1}=0.99 \times 0.95 \times 0.95 \times 0.95 \times 0.95 \times 0.95 \times 0.95=0.73$;

$$
K_{e 1}=1.00 \text {. }
$$

The land plot is suggested to be exchanged with a land plot in Desnyanskiy district, Kyiv, Troeschyna village (economic planning zone No. 574, $K_{p 3}=0.78(\mathrm{Ky}-$ ivska miska administratsiia 2007)). Functional usage is the same for both plots - residential housing land. It is assumed, the assignment of rectangular land plot with the side ratio 1:5 (according to formula (3) $K_{f}=$ 0.83 ) is provisioned. Real estate units are not situated on the envisaged to exchange land plot, no easements or servitudes $\left(K_{e}=1.00\right)$.

The constituents of the Equation (2) for the provisioned to exchange land plot:

$$
\begin{gathered}
K_{p l 2}=3.00 \times 0.78=2.34 ; \\
K_{p h 2}=0.83 \\
K_{e 2}=1.00
\end{gathered}
$$

From Equation (2):

$$
\begin{gathered}
S_{1}=\frac{S 1 \times K_{p l 1} \times K_{p h 1} \times K_{e 1}}{K_{p l 2} \times K_{p h 2} \times K_{e 2}} ; \\
S_{2}=\frac{1200 \times 2.43 \times 0.73 \times 1.00}{2.34 \times 0.83 \times 1.00}=1091 \mathrm{~m}^{2} .
\end{gathered}
$$

\section{Conclusions}

Land exchange is an important component of land reallocation projects aiming at a set of public goals, nature conservation and urban space improvement. However, usually peer land exchange is based on the existing legislation of the country, has procedure peculiarities and should take into consideration a set of auxiliary local conditions. Considering this, the improvement of peer land exchange process in Ukraine based on the unified computation is suggested. The provided computation allows considering the key land valuation impact factors.

For built-up (or to be built-up) land peer exchange should consider principal placement characteristics and physical characteristics of land plots impacting their usage and usage restrictions.

With the provided approach, technical data characterizing the principal impact factors and peer land plots for exchange in Kyiv were calculated.

\section{References}

Attenberger, J. 2002. The right mix of instruments - land consolidation, land management and land banking in Bavaria, in International Symposium "Land Fragmentation and Land Consolidation in CEEC: A gate towards sustainable rural development in the new millennium", 25-28 February 2002, Munich, Germany.

Bugaienko, O. 2015. Doslidzhennia faktoriv, shcho vplyvaiut na provedennia rivnotsinnoho obminu zemelnykh dilianok silskohospodarskoho pryznachennia, Mistobuduvannia ta terytorialne planuvannia 57: 73-78 (in Ukrainian).

Chibiriakov, V.; Malashevskyi, N.; Bugaienko, O. 2015. Vdoskonalennia metodyky rozrakhunku rivnotsinnykh zemelnykh dilianok silskohospodarskoho pryznachennia pry provedenni obminu, Inzhenerna heodeziia 62: 85-94 (in Ukrainian).

De Moor, A. 2015. Urban land reallotment in Geodesign Summit Europe, 27-28 January 2015, Salzburg, Austria [online], [cited 04 February 2016]. Available from Internet: http:// proceedings.esri.com/library/userconf/geodesign-euro15/ papers/geoeuro_10.pdf

Derzhavnyi komitet Ukrainy po zemelnykh resursakh, Ministerstvo ahrarnoi polityky Ukrainy, Ministerstvo budivnytstva, arkhitektury ta zhytlovo-komunalnoho hospodarstva Ukrainy, Ukrainska akademiia ahrarnykh nauk. 2006. Pro poriadok normatyvnoi hroshovoi otsinky zemel silskohospodarskoho pryznachennia ta naselenykh punktiv, Ofitsiinyi visnyk Ukrainy 15: 154 (in Ukrainian).

Drees, A. 2002. Challenges in East German States, in International Symposium "Land Fragmentation and Land Consolidation in CEEC: A gate towards sustainable rural development in the new millennium", 25-28 February 2002, Munich, Germany.

FAO. 2003. The design of land consolidation pilot projects in Central and Eastern Europe. FAO Land Tenure Studies no. 6. Rome.

FAO. 2004. Operations manual for land consolidation pilot projects in Central and Eastern Europe. FAO Land Tenure Manuals no. 1. Rome.

Giovarelli, R.; Bledsoe, D. 2001. Land reform in Eastern Europe - Western CIS, Transcaucuses, Balkans, and EU Accession Countries [online], [cited 01 October 2001]. FAO. Available from Internet: http://www.fao.org/3/a-ad878e.pdf

Hartvigsen, M. 2014. Land mobility in a Central and Eastern European land consolidation context, Nordic Journal of Surveying and Real Estate Research 10 (1): 23-46.

Hartvigsen, M. 2015. Experiences with land consolidation and land banking in Central and Eastern Europe after 1989. FAO Land Tenure Working Paper 24 [online], [cited 02 February 2015]. Available from Internet: http://www.fao.org/3/ai4352e.pdf

Hendricks, A.; Lisec, A. 2013. Land consolidation for large-scale infrastructure projects in Germany, Journal of the Association of Surveyors of Slovenia 58(1): 46-68.

Kyivska miska administratsiia. 2007. Normatyvna hroshova otsinka zemel $m$. Kyieva. Technical documentation (in Ukrainian).

Malashevskyi, N.; Mosiichuk, Yu.; Bugaienko, O. 2014. Doslidzhennia vitchyznianoho dosvidu obminu zemel silskohospodarskoho pryznachennia, Inzhenerna heodeziia 61: 85-94 (in Ukrainian).

Thomas, J. 2006. What's on regarding land consolidation in Europe [online], [cited 13 October 2006]. FAO. Available from Internet: https://www.fig.net/resources/proceedings/fig_proceedings/fig2006/papers/ts80/ts80_03_thomas_0311.pdf 
Thomas, J. 2012. Land consolidation as alternative to compulsory land acquisition in case of big public infrastructure projects, in 3rd international LANDNET workshop on Land Market Development and Land Consolidation, 13-16 February 2012, Budapest, Hungary. [online], [cited 04 February 2015]. Available from Internet: http://www.fao.org/fileadmin/user_ upload/Europe/documents/Events_2012/3LANDNET/18_ en.pdf
Mykola MALASHEVSKYI. PhD candidate in Geodesy at Kyiv National University of Construction and Architecture (2011). Associate Professor, The Head of Land Management, Cadastre and Geoinformatics Department, Institute of Advanced Education of Kyiv National University of Construction and Architecture. Research interests: land management, land and real estate valuation, land and agrarian reforms, cadastral surveying, reference systems.

Olena BUGAIENKO. Assistant, Land Management and Cadastre Department, Kyiv National University of Construction and Architecture. A graduate of Kyiv National University of Construction and Architecture, MSc, 2013. Research interests: land management, land valuation, cadastre, land use planning. 